\title{
Optimization of Eugenol Extraction from Clove Oil using Response Surface Methodology
}

\author{
Widayat $^{1}$, Hadiyanto ${ }^{1}$, Bambang Cahyono ${ }^{2} \&$ Ngadiwiyana $^{2}$ \\ ${ }^{1}$ Department of Chemical Engineering, Diponegoro University, Indonesia \\ ${ }^{2}$ Department of Chemistry, Diponegoro University, Indonesia \\ Correspondence: Hadiyanto, Department of Chemical Engineering, Diponegoro University, Indonesia. Tel: \\ 62-247-460-058. E-mail: h.hadiyanto@undip.ac.id
}

Received: May 8, 2015

Accepted: June 29, 2015

Online Published: September 30, 2015

doi:10.5539/mas.v9n11p68

URL: http://dx.doi.org/10.5539/mas.v9n11p68

The research is financed by MP3EI research grant 2013, Directorate General of Higher Education, Ministry of Education and Culture, Indonesia.

\begin{abstract}
The objective of this research was to obtain optimum condition of eugenol production from clove oil using a central composite design method. The main process occured in the eugenol production was saphonification and neutralization processes. In order to optimize these processes, the ratio of $\mathrm{NaOH} / \mathrm{clove}$ oil and temperature were studied as design variables i.e. ratio of $\mathrm{NaOH} / \mathrm{clove}$ oil $=1: 2.5-1: 3.5$ while temperature was varied between 40 and $60 \mathrm{oC}$. The yield of eugenol was considered as the main response in of this experiment. The result showed that the optimum condition was achieved when the temperature and the ratio of $\mathrm{NaOH} / \mathrm{clove}$ oil were $50 \mathrm{oC}$ and $2.75: 1$, respectively and the yield was $39.17 \%$.
\end{abstract}

Keywords: eugenol, clove oil, saponification -neutralization process, yield of eugenol, and Response surface response methods (RSM)

\section{Introduction}

Since the production of clove oil has reached 250 tons in 2011, Batang regency has been considered as one of the largest producers of clove oil in Indonesia (Widayat et al, 2011). The clove oil is mostly extracted from part of clove plants (Eugenia caryophyllata thunb) such as leaves, flower, and stem. The quality of cloves oil is determined by the content of phenol compound, especially eugenol (BSN, 2010) which is still considered as the main problem of clove oil in Indonesia. Currently, the clove oil still has high content of eugenol and it is higher than the National Indonesian Standard (SNI). It has been reported that most of clove oil at small medium entrepreneurship (SME) in Batang Regency have eugenol contents up to 80\%(Widayat et al, 2014) . Besides eugenol, the clove oil is also determined by $\beta$-Caryophyllene, an impurities that decrease the clove oil quality (Widayat et al, 2014).

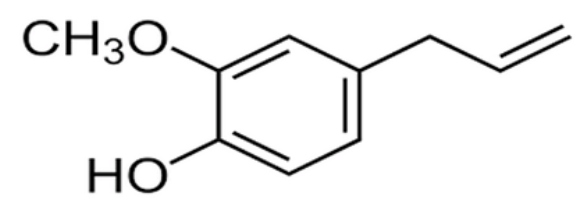

Figure 1. The molecule structure of eugenol

However, besides it is resulted from side product of clove oil, eugenol has potential for industries. Eugenol or Phenol, 2-methoxy-4-(2-propenyl) (Figure 1) is the main component of clove oil and it is colourless, has spicy taste and special odour which therefore it was mostly used for fragrance and flavour industries. The eugenol is also mostly utilized in the perfume industries, flavor concentrates and in the pharmaceutical industries as an antiseptic and anesthetic drug. Oyedemi et al. (2009) reported that eugenol is efficient for the metabolic activity 
of bacteria Listeria monocytogenes, Streptococcus pyogenes, Escherichia coli and Proteus vulgaris. Furthermore, Cheng et al. (2008) has utilized this compound and sinamaldehid as an anti-fungal for the type of fungus and Laetiporus sulphureus, which is considerable used as activity inhibitory. Shelly et al. (2010) used eugenol derivative such as methyl eugenol to effectively increase the fertility of insects. Sadeghian et. al., (2008) had utilized eugenol derivatives to inhibit the activity of the enzyme 15-lipogenase which is involved in many diseases such as asthma and lung cancer. The results showed that these compounds could inhibit the performance of the enzyme 15-lipogenase. Furthermore, Chami et al. (2004) also have tested eugenol as anti fungus Candida albicans. Vidhya and Devaraj (2011) experienced eugenol for inducing lung cancer, which showed inhibitory phenomena in lung cancer.

The price of clove oil is determined by its purity, the clove oil with purity under $70 \%$ will have price of Rp $120.000,00 / \mathrm{kg}$, while the clove oil with purity $98 \%$ have price of $500.000 / \mathrm{kg}$. Therefore, extraction and separation of eugenol from clove oil is an essential step to obtain such valuable product. According to USP (United States Pharmacopeia) standard, eugenol product must have purity higher than $98 \%$.

Another aspect for increasing eugenol contents is by implementation of chelating agent to reduce the darkness. The chelating agents that mostly used are as citric acid and sodium EDTA(Marwati et al, 2005). Commonly, this process can increase eugenol contents up to $80 \%$. Another process for separation of eugenol from clove oil is by using saponification and distillation as well as fractionation. In this method, sodium hydroxide will be reacted with clove oil and then was neutralized by adding sulphuric acid or hydrochloride acid. The eugenol product then is separated using decantation and distillation process. This process could increase eugenol contents up to $82,6 \%$ (minimum)(Anny, 2002; Sukarsono et al, 2003). However, the optimization is still required to estimate the associated variables in eugenol production. Therefore, the objective of this research was to conduct optimization of eugenol production from clove oil using neutralization process and fractional distillation by using Response Surface Methodology (RSM).

\section{Method}

\subsection{Materials}

The clove oil used in this study was obtained from essential oils cluster Batang District. The clove oil has eugenol contents of $80 \%$.

The equipment used for saponification and distillation process is presented in Figure 2. The distillation was operated in vacuum pressure that obtained with vacuum pump. Distillation column used packing system.

\subsection{Experimental Design}

The experimental design used is Response Surface Methodology (RSM) as described in Table 1 with two variables: the operation temperature and the ratio of clove oil to sodium hydroxide $(\mathrm{NaOH})$. Experiment process were performed on a laboratory scale and batch processes. The operating conditions used as follows:

a. Fixed Variables

$$
\begin{array}{lll}
\checkmark & \text { Clove oil volume }(\mathrm{ml}) & : 150 \\
\checkmark & \text { Materials } & : \text { clove oil } \\
\checkmark & \text { Operational time } & : 45 \text { minute }
\end{array}
$$

b. Experimental variables:
- Temperature
: $(-1):(40)$ and $(+1)(60)^{\circ} \mathrm{C}$
- Ratio $\mathrm{NaOH} / \mathrm{Clove}$ oil (v/v)
: $\quad(-1)(2,5)$ and $(+1)(3,5)$ 


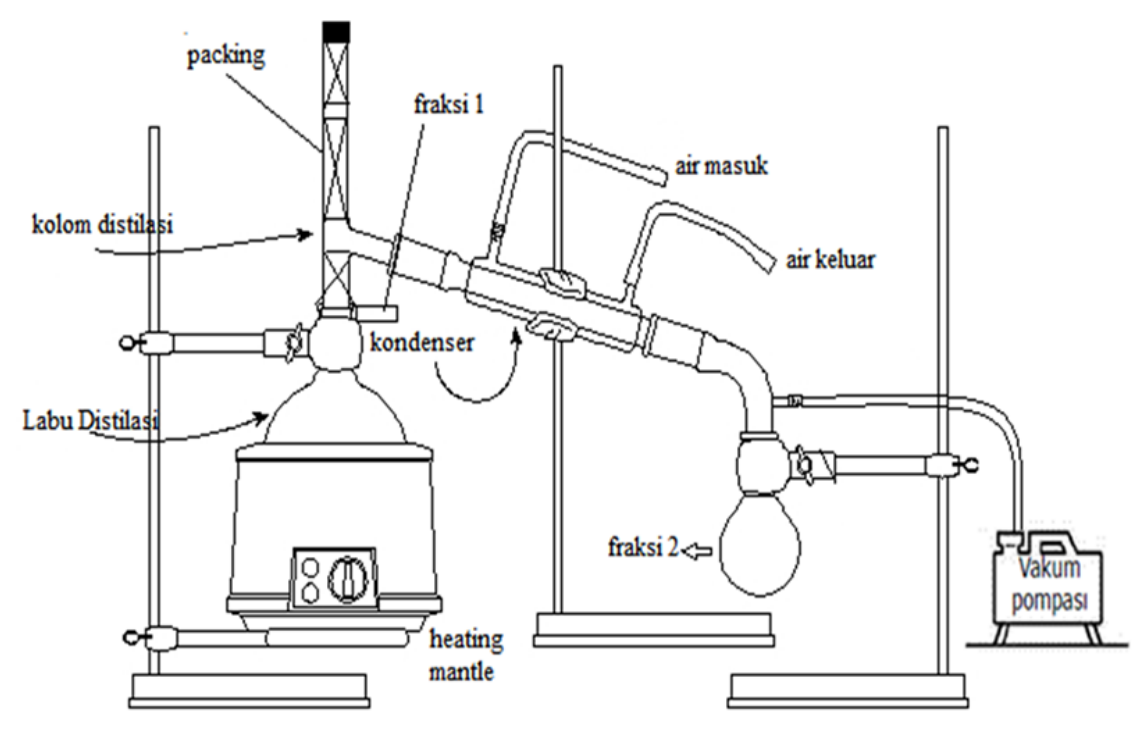

Figure 2. Vacuum Distillation equipment

\subsection{Procedure}

The experiments began with oil density measurement and specific volume of clove leaf oil. Prior to experiment, clove oil was purified using citric acid(Widayat et al, 2014). A $150 \mathrm{ml}$ of clove oil and $\mathrm{NaOH}$ were added under specified ratios of variables. The saponification reaction occurred for 45 minutes, and then followed by decantation for 1 day. The formed soaps were then neutralized with hydrochloride acid and were reacted for 5 minutes. This process was continued by decantation for 15 minutes. The eugenl product ws purified by using distillation for 1.5 hours. The final product was collected and was measured for its volume and refractive index. The concentration of products was also analyzed by using GC and data was analyzed by using STATISTICA.

Table 1. Variable Central Composite Design for Experiment

\begin{tabular}{ccccc}
\hline Run & Block & $\mathbf{X}_{\mathbf{1}}$ & $\mathbf{X}_{\mathbf{2}}$ & $\mathbf{Y}$ \\
\hline 1 & 1 & -1 & -1 & $\mathrm{Y}_{1}$ \\
2 & 1 & -1 & +1 & $\mathrm{Y}_{2}$ \\
3 & 1 & +1 & -1 & $\mathrm{Y}_{3}$ \\
4 & 1 & +1 & +1 & $\mathrm{Y}_{4}$ \\
5 & 1 & 0 & 0 & $\mathrm{Y}_{5}$ \\
6 & 2 & 0 & $-1,424$ & $\mathrm{Y}_{6}$ \\
7 & 2 & 0 & $+1,424$ & $\mathrm{Y}_{7}$ \\
8 & 2 & $-1,424$ & 0 & $\mathrm{Y}_{8}$ \\
9 & 2 & $+1,424$ & 0 & $\mathrm{Y}_{9}$ \\
10 & 2 & 0 & 0 & $\mathrm{Y}_{10}$ \\
\hline
\end{tabular}

Where:

$\mathrm{X}_{1}=$ Coded variables for ratio of oil to $\mathrm{NaOH}$

$\mathrm{X}_{2}=$ Coded variables for temperature

$\mathrm{Y} \quad=$ Yield of eugenol (\%)

\subsection{Data Analysis}

The responses of this experiment were density, viscosity and eugenol concentration. The eugenol concentration 
was analyzed by using gas chromatography at Malang Polytechnic Laboratory. The liquid product was analysed by using gas chromatography (HP 5890, with HP 608 column) equipped with FID detector. The operating condition used helium as gas carries with flow rate of $20 \mathrm{ml} /$ minute, temperature of $100-200{ }^{\circ} \mathrm{C}$ with temperature gradient $5 \%$ minute and initial time 5 minute. Detector temperature was $275^{\circ} \mathrm{C}$. The product was analysed with internal standard methods. $6 \mu \mathrm{L}$ eugenol standard solutions was added with internal standard (benzyl alcohol) 6 $\mu \mathrm{L}$ and $1 \mathrm{ml}$ of solvent. The solution injected on GC equipment and conducted in triple runs. The response of detector was calculated with sample area divided internal standard area. The yield of eugenol was calculated according to Eq 1 .

$$
\text { Yield }(\%)=\frac{\text { weight of eugenol }}{\text { weight of clove oil }} \times 100
$$

\section{Results}

\subsection{Chromatography Analysis}

Fig. 3 shows the chromatogram analysis of methanol(solvent), benzyl alcohol and eugenol with retention time of $3.39 ; 10.04$ and 18.36 minute, respectively. According to this chromatogram, the eugenol contents in the product were varies between 75.10 to $96.00 \%$. This result showed that the euogenol producton could achieve higher concentration of eugenol from clove oil. Figure 3a shows a chromatogram of eugenol and internal standard and Figure 3.b for sample product and both figures show similarities, although there was a small shift of retention time.
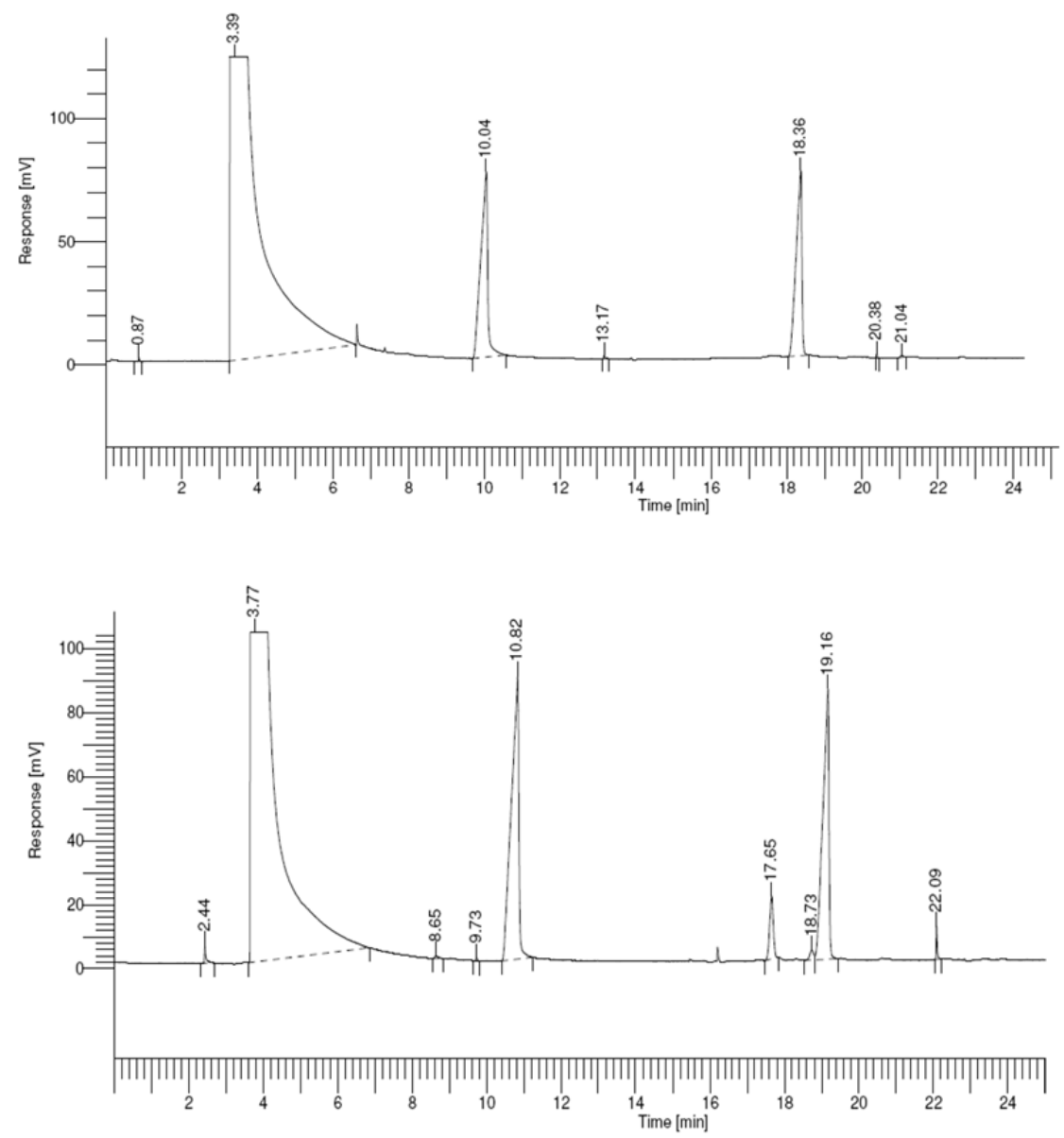

Figure 3. Chromatogram of eugenol (a). Eugenol and internal standards, (b). Sample with internal standard 


\subsection{Response Surface Methods}

The results of statistic analysis was performed by developing mathematical model, $t$ test, analysis of variance, pareto analysis as well as model validation. The polynomial equation of multi linear regression was proposed by following form:

$$
\mathrm{Y}=\mathrm{X}_{\mathrm{o}}+\beta_{1} \mathrm{X}_{1}+\beta_{2} \mathrm{X}_{2}+\beta_{11} \mathrm{X}_{1}^{2}+\beta_{22} \mathrm{X}_{2}^{2}+\beta_{12} \mathrm{X}_{1} \mathrm{X}_{2}
$$

Where:

$\mathrm{Y}=$ predicted response

$\beta_{1}, \beta_{2}=$ linear coefficient for 1,2 variable

$\beta_{11}, \beta_{22}=$ squared term coefficient for 1,2 variable

$\beta_{12}=$ interactions variable coefficient

$\mathrm{X}_{1}:, \mathrm{X}_{2} \quad=$ non dimensional number of independent variables

The variable or coefficients were obtained by determining the multi linear regression by using STATISTICA software. Through this software, the coefficients were obtained and showed by Eq 3 .

$$
\begin{aligned}
Y= & 34.4639-0.5886 X_{1}+19.6363 X_{1}^{2}-5.6989 X_{2} \\
& +9.2652 X_{2}^{2}+3.2853 X_{1} X_{2}
\end{aligned}
$$

This equation represents correlation between yield of eugenol and realted parmeters to obtain the yield. However, this variable of $\mathrm{X} 1$ and $\mathrm{X} 2$ are still in coded variable. The real values of condition process must be determined inversely.

In Eq 3, it is shown that the values of coefficient for $X_{1}$ and $X_{2}$ are negative. This leads to the fact that if the ratio of oil to $\mathrm{NaOH}\left(\mathrm{X}_{1}\right)$ and temperature $\left(\mathrm{X}_{2}\right)$ increase then the yield of eugenol will decrease (for $\mathrm{X}_{1}$ and $\mathrm{X}_{2}>0$ ). In addition, the interaction between $\mathrm{X} 1$ and $\mathrm{X} 2$ and also quadratic variable are positive, which means that the increase of both variables will also increase of the eugenol yield. The complete statistical analysis of coefficient by using multivariate variables in Eq 3 is shown by Table 2 .

Table 2. Regression analysis result

\begin{tabular}{ccccccc}
\hline Parameters & Regression & Std.Err. & $\mathbf{t ( 3 )}$ & $\mathbf{p}$ & $\mathbf{- 9 5 . \%}$ & $\mathbf{+ 9 5 . \%}$ \\
\hline Mean/Interc. & 34.4639 & 11.0747 & 3.1119 & 0.0528 & -0.7808 & 69.7085 \\
Blocking & -5.5849 & 4.9528 & -1.1276 & 0.3415 & -21.3468 & 10.1770 \\
$\mathbf{X}_{\mathbf{1}}$ & -0.5886 & 5.5374 & -0.1063 & 0.9221 & -18.2109 & 17.0337 \\
$\mathbf{X}_{\mathbf{1}}{ }^{2}$ & 19.6363 & 7.3252 & 2.6806 & 0.0750 & -3.6759 & 42.9485 \\
$\mathbf{X}_{\mathbf{2}}$ & -5.6989 & 5.5374 & -1.0292 & 0.3791 & -23.3212 & 11.9235 \\
$\mathbf{X}_{\mathbf{2}}{ }^{2}$ & 9.2652 & 7.3252 & 1.2648 & 0.2952 & -14.0470 & 32.5773 \\
$\mathbf{X}_{\mathbf{1}} \mathbf{X}_{\mathbf{2}}$ & 3.2853 & 7.8310 & 0.4195 & 0.7031 & -21.6365 & 28.2070 \\
\hline
\end{tabular}

Variance of mathematical model was analyzed and the results presented in Table 3. Table 3 can also be used to determine whether the independent variables simultaneously significant effect on the dependent variable. The degree of confidence was 0.05 (Bos et al, 2005; Lazic, 2004)). The parameters have $\mathrm{F}$ value more than $\mathrm{p}$ for all parameters except for X1 quadratic variable $(\mathrm{F}$ value $=0.0113 \mathrm{p}=0.9221)$ and interaction variable $(\mathrm{F}=0.1759$ and $\mathrm{p}=0.2953$ ). The results of variance analysis support the t-test in Table 2 for $\mathrm{X} 1$ and $\mathrm{X} 2$ variable (single variable). It also shows that the mathematical model already in optimum condition (maximum / minimum) no stripes ascend and mathematical model can be used directly for optimization. 
Table 3. Analysis of variance(ANOVA)

\begin{tabular}{crcrrr}
\hline Parameter & \multicolumn{1}{c}{ SS } & df & \multicolumn{1}{c}{ MS } & \multicolumn{1}{l}{ F } & p \\
\hline Blocks & 311.911 & 1 & 311.911 & 1.2716 & 0.3415 \\
$\mathbf{X}_{\mathbf{1}}$ & 2.771 & 1 & 2.771 & 0.0113 & 0.9221 \\
$\mathbf{X}_{\mathbf{1}}{ }^{2}$ & 1762.671 & 1 & 1762.671 & 7.1858 & 0.0750 \\
$\mathbf{X}_{\mathbf{2}}$ & 259.816 & 1 & 259.816 & 1.0592 & 0.3791 \\
$\mathbf{X}_{\mathbf{2}}{ }^{2}$ & 392.427 & 1 & 392.427 & 1.5998 & 0.2953 \\
$\mathbf{X}_{\mathbf{1}} \mathbf{X}_{\mathbf{2}}$ & 43.172 & 1 & 43.172 & 0.1759 & 0.7031 \\
Error & 735.896 & 3 & 245.299 & & \\
Total SS & 3120.280 & 9 & & & \\
\hline
\end{tabular}

Pareto diagram can be a help to assist determination of the most important parameter in the process(Lazic ,2004). Pareto diagram (Figure 4) show that a linear variable X2 has the smallest value. Therefore this variable can be neglected due to no having effect in the process. All histogram of variables don't cross the line $p=0.05$. Pareto chart show quadratic variable of X22 which has a histogram near to line $p=0.05$. This proofs that quadratic variable X22 has the most effect in the eugenol yield. This condition can be increased for obtaining the optimum condition.

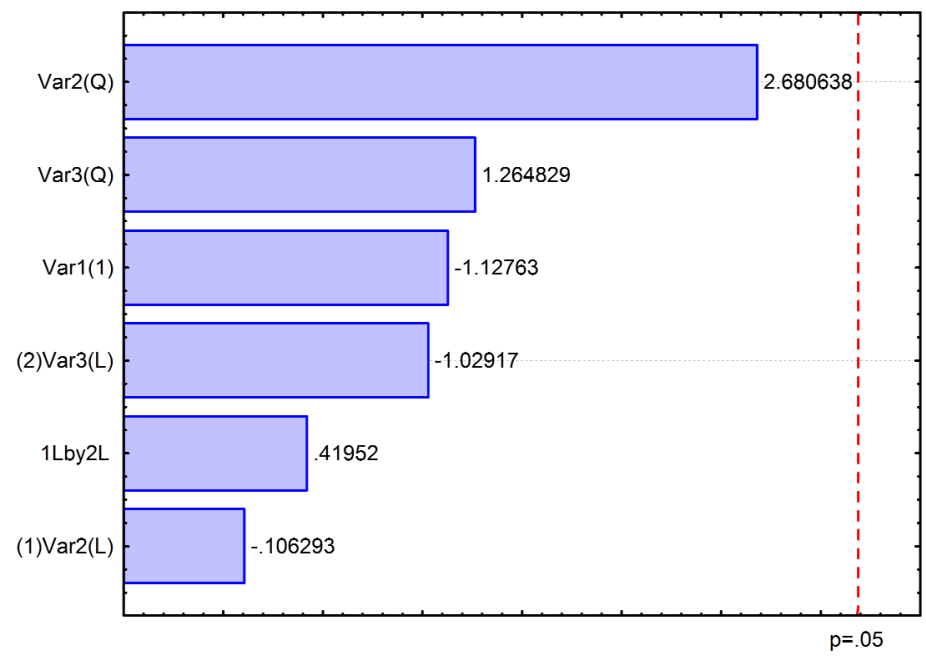

Figure 4. Parreto Diagram

Figure 5 shows optimum condition in term of a surface response graph that consists of $\mathrm{x}$ and $\mathrm{y}$ axis as independent variable $\left(\mathrm{X}_{1}\right.$ and $\left.\mathrm{X}_{2}\right)$ and $\mathrm{z}$-axis as dependent variable or yield of eugenol $(\mathrm{Y})$. Figure 5 has a minimum poin meaning that the process is already minimized. 


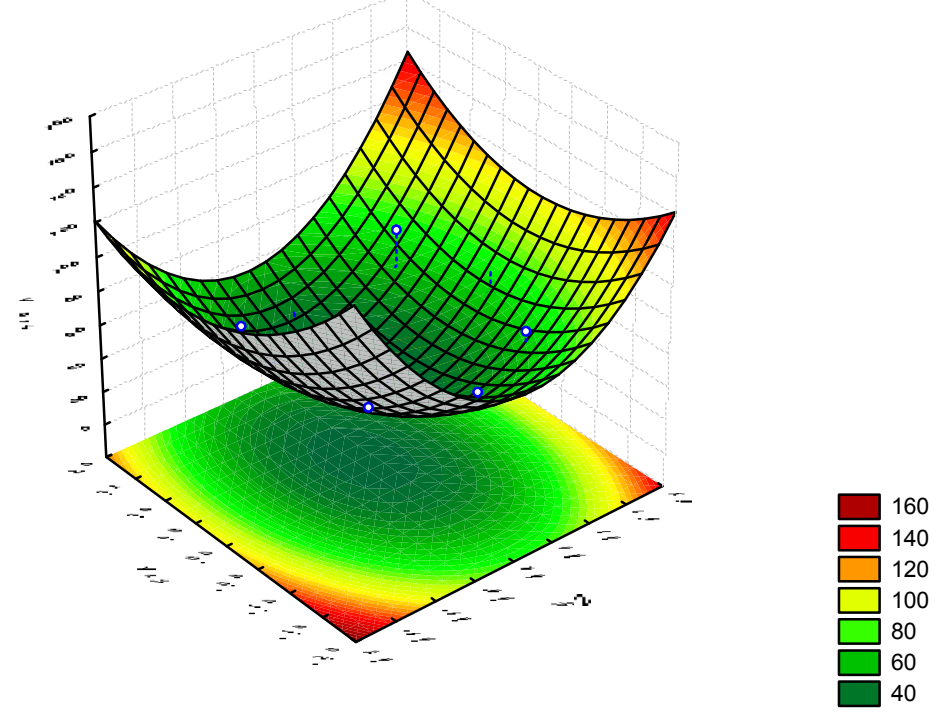

Figure 5. Countour Graphics of optimization results material ratio and temperature

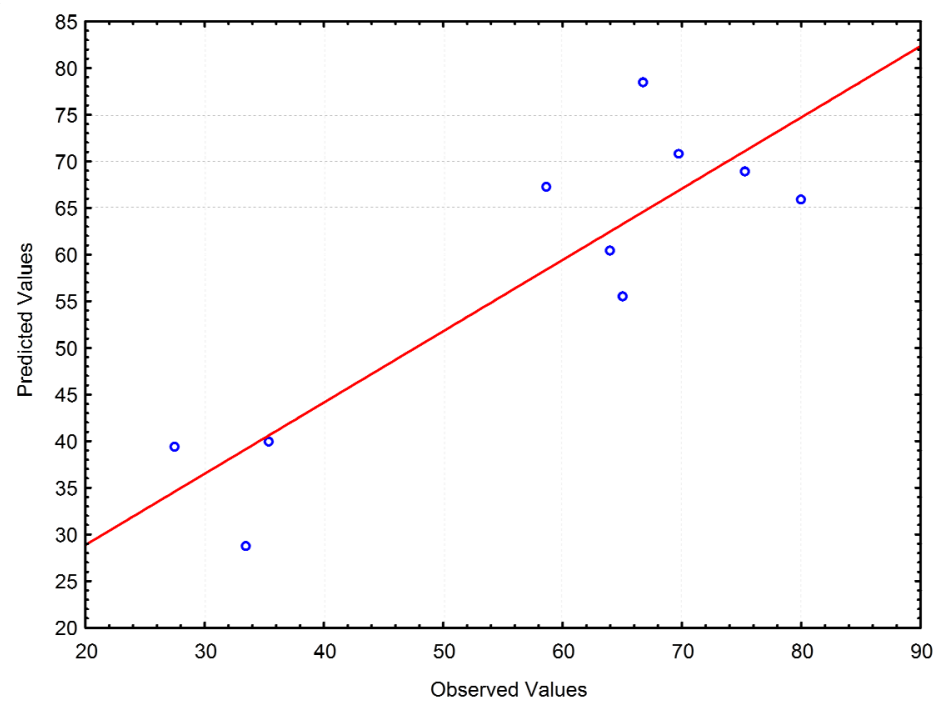

Figure 6. Model validations with experimental data

Mathematical model described by equations 3 was validated with experiments data (Figure 6). Figure 6 also shows that the mathematical model has lower significant regression value $\left(\mathrm{R}^{2}=0.764\right)$. However, such value is still suficient to obtain the optimum condition.

In Table 4, the critical value of dimensionless numbers for each variable. Critical dimensionless value obtained for X1 (ratio clove oil to sodium hydroxide) is -0.0109 and X2 (temperature) 0.3095 . X1 and X2 critical value is substituted to equation 6 to obtained yield of eugenol. Yield of eugenol in minimum condition is $39.17 \%$. 
Table 4. Critical value results / optimization

\begin{tabular}{cccc}
\hline & \multicolumn{3}{c}{ Solution: minimum } \\
\cline { 2 - 4 } & Observed & Critical & Observed \\
\hline $\mathbf{X}_{\mathbf{1}}$ & -1.4142 & -0.0109 & 1.4142 \\
$\mathbf{X}_{\mathbf{2}}$ & -1.4142 & 0.3095 & 1.4142 \\
\hline
\end{tabular}

\section{Discussion}

The clove oil has been purified and separated from its eugenol contents. Eugenol which is one of indicator for quality of clove oil has been considered also as an important product for food industries. The result shows that 75-96\% eugenol can be extracted from cloe oil by using separation method of saphonification, and distillation.

The Surface Response Method (SRM) has been employed for optimization and analysis of production and purification of eugenol from clove oil by using neutralization and fractionation distillation. The minimum yield was obtained as $39.17 \%$ under $\mathrm{X}_{1}$ (ratio clove oil to sodium hydroxide) is -0.0109 (equal to $2.75: 1$ ) and $\mathrm{X}_{2}$ (temperature) of 0.3095 (equal to $55^{\circ} \mathrm{C}$ ). The regression coefficient for the mathematical model was achieved at $\mathrm{R}^{2}=0.7642$.

The further research is required to increase the eugenol purity and yield. Conventional steam distillation is typically considered the best way to obtain essential oils including eugenol from clove oil. However, this method produces varying eugenol product qualities dependent upon the temperature, pressure and time used for distillation. An important point regarding steam distillation of eugenol oils is that the temperature involved in the process changes the molecular composition of the plant matter. However, in practice most essential oils including eugenol are obtained by distillation at rather elevated temperature, in order to optimize the yield. Other alternative were proposed to use process intensification through microwave, ultrasound or supercritical fluid extraction and distillation. However, their economical feasibility must also be considered. Further action is also required to investigate the eugenol risk to human in term of their use for food.

\section{Conclusion}

This study showed the distillation process of eugenol out of clove oil. The distillation method give much better improvements in term of its yield and purity of products. The optimum condition was achieved when the temperature $55 \mathrm{oC}$ and the ratio of clove oil/ $\mathrm{NaOH}$ was $2.75: 1$.

Further improvement is required to increase the yield by using process intensification through microwave, ultrasound or supercritical technology.

\section{Acknowledgement}

The authors would like to express sincerely thanks to Higher Education Directorate, Ministry of Education and Culture for their support in providing MP3EI 2013 research grant.

\section{References}

Anny, S. (2002). Pengolahan Lanjut Minyak Atsiri dan Penggunaannya Dalam Negeri. Workshop Nasional Minyak Atsiri 30 Oktober 2002, Dirjen Industri Kecil Dagang Menengah, Depperindag.

Box, G. EP., Hunter, J. S., \& Hunter, W. G. (2005). Statistics for Experiments second edition. John Wiley and Sons, New York.

BSN (Badan Standarisasi Nasional). (2010). Standar Nasional Indonesia Minyak Daun Cengkeh. SNI 06-2387-2006 2006.

Chami, N., Chami, F., Bennis, S., Trouillas, J., \& Remmal, A. (2004). Antifungal treatment with carvacrol and eugenol of oral candidiasis in immunosuppressed rats. Braz. J. Infect. Dis., 8(3), 217-226.

Lazic, Z. (2004). Statistics Experiments for Chemical engineering. WILEY-VCH Verlag GmbH \& Co. KGaA, Weinheim.

Marwati, T., Rusli, M. S., Noor, E., \& Mulyono, E. (2005). Peningkatan Mutu Minyak Daun Cengkeh Melalui Proses Pemurnian. Jurnal Pasca Panen, 2, 45-52.

Oyedemi, S. O., Okoh, A. I., Mabinya, L.V., Pirochenva, G., \& Afolayan, A. J. (2009). The proposed mechanism of bactericidal action of eugenol, $\alpha$-terpineol and $\alpha$-terpinene against listeria monocytogenes, Streptococcus pyogenes, Proteus vulgaris and Escherichia coli. Afr. J. Biotechnol., 8(7), 1280-1286.

Sadeghian, H., Seyedi, S. M., Saberi, M. R., Arghiania, Z., \& Riazi, M. (2008). Design and synthesis of eugenol 
derivatives, as potent 15-lipoxygenase inhibitors. Bioorgan. Med. Chem., 16, 890-901.

Shelly, T. E., Edu, J., \& McInnis, D. (2010). Pre-release consumption of methyl eugenol increases the mating competitiveness of sterile males of the oriental fruit fly, Bactrocera dorsalis, in large field enclosures. $J$. Insect Sci., 10, 8 .

Sukarsono, Dahroni, I., \& Sucahyo, D. H. (2003). Kajian Pemisahan Komponen - komponen dari Minyak Cengkeh". Yogyakarta Puslitbang Teknologi Maju BATAN.

Vidhya, N. and S.N. Devaraj, (2011). Induction of apoptosis by eugenol in human breast cancer cells. Indian J. Exp. Biol., 49: 871-878.

Widayat, Cahyono B., Hadiyanto \& Ngadiwiyana. (2014). Improvement of Clove Oil Quality by Using Adsorption-distillation Process. Research Journal of Applied Sciences, Engineering and Technology, 7(18), 3867-3871,

Widayat, Cahyono, B, Hadiyanto \& Ngadiwiyono. (2011). Rancang Bangun dan Uji Alat Proses Peningkatan Minyak Cengkeh Pada Klaster Minyak Atsiri kabupaten Batang. Jurnal Ilmu Lingkungan, 9(2), 57-61.

Widayat, Haidar, M. H., Nurdiana, L., Cahyono B., Ngadiwiyana, \& Satriadi, H. (2013). Fractional Distillation of Clove Oil at Vacuum Pressure, Proceeding International Seminar 2013 Faculty of Engineering University Muhammadiyah Purwokerto.

\section{Copyrights}

Copyright for this article is retained by the author(s), with first publication rights granted to the journal.

This is an open-access article distributed under the terms and conditions of the Creative Commons Attribution license (http://creativecommons.org/licenses/by/3.0/). 